\title{
Små barns berättelser om sexuella övergrepp
}

\author{
ANN-CHRISTIN CEDERBORG
}

\begin{abstract}
Den här studien belyser förskol ebarns ojämnlika position i polisförhör där de misstänks ha varit utsatta för sexuella övergrepp. Den juridiska instansen har att bedöma trovärdigheten i en berättel se om sexuell a övergrepp. U tsagor från barn är ofta de enda bevis som jurister har att utgå ifrån vid avgörandet om övergrepp skett ell er inte.
\end{abstract}

Sedan år 1995 bedriver jag forskningsprojektet, »Sexuella övergrepp mot barn. Analys av polisförhör med barn som misstänks varit utsatta för sexuella övergrepp samt genomgång av deras domstolsprotokoll« vid Linköpings Universitet. Syftet med projektet är att öka förståelsen för hur berättelser samproduceras mellan barn och polis och att skapaförståelse för hur det juridiska systemet hanterar och beskriver barns trovärdighet i den här typen av ärenden. Projektet är finansierat av Socialvetenskapliga Forskningsrådet. Resultaten från hela projektet bygger på ett empiriskt material med 193 videoinspelade polisförhör med barn i åldrarna 2-18 år i en medelstor svensk stad.

Ann-Christin C ederborg är universitetslektor i psykologi och verksam vid Institutionen för Pedagogik och Psykologi och Tema Barn vid Linköpings Universitet. Hennes huvudsakliga forskningsintressen rör sig inom fältet för barns och ungdomars livsvillkor men handlar också om hur barn och ungdomar hanterar, och förstås av de agerande i, olika institutionella miljöer.
Barnen misstänks ha varit utsatta för sexuella övergrepp under perioden 1986-1995 och totalt förhörde sex poliser dessa barn.

Det huvudsakliga syftet med den här delstudien är att söka förstå hur förskolebarn och poliser samproducerar berättelser om sexuella övergrepp. A rtikeln belyser barnets asymmetriska position i polisförhör och undersökningen grundar sig på en analys av 54 videoinspel ade polisintervjuer med barn i åldrarna 2-7 år som tros ha varit utsatta för sexuell a övergrepp. Barnen förhördes av civilklädda poliser oftast på polisstationen men också på barnkliniken i staden. Barnen videoförhördes mestadels ensamma.

Utifrån ett juridiskt perspektiv är det svårt att bevisa att sexuella övergrepp har förekommit. Det saknas ofta fysiska bevis eller vittnen till det misstänkta övergreppet. Utsagor från barn är ofta det end a bevis som jurister har att utgå ifrån vid avgörandet om övergrepp har skett eller inte. 0 av- 
sett om det finns stöd $\mathrm{i}$ andra bevis om ett brott har begåtts eller inte blir frågan om barns trovärdighet avgörande för utfallet av ett ärende (G regow, 1996).

Barns förmåga att minnas och återge upplevelser och erfarenheter av sexuella övergrepp har diskuterats och ifrågasatts både i den allmänna debatten och inom juridiken men också bland forskare och kliniskt verksamma personer. Enskilda fall har också uppmärksammats och diskuterđs i pressen och dessa har exempelvis handlat om barn som återtagit sina berättelser om övergrepp. Forskare har ifrågasatt om återgivningar av övergrepp har sitt ursprung i verkliga händelser eller om berättelserna ska förstås som fantasiprodukter samproducerade av exempelvis psykoterapeuter och barn (se exempelvis C ampell, 1994; Loftus, 1995).

I sina avgöranden har Högsta D omstolen (HD) uppställt vissa kriterier för en trovärdig berättelse. Berättelsen, bör enligt HD, vara sammanhängande, klar och detaljerad och inte innehåll a punkter som verkar svårförklarliga eller på annat sätt väcker tveksamhet om berättarens trovärdighet (HD:S dom 199311 24, DB 688). HD :s ställningstaganden har dock ifrågasatts av Justitierådet G regow (1996). G regow hävdar att en sammanhängande berättelse inte alltid kan förväntas och inte heller behöver vara en förutsättning för att uppgifterna ska kunna anses som trovärdiga. Diesen (1996) belyser betydelsen av en personlighets- och åldersadekvat berättelse. Detta innebär att innehållet i berättelsen ska stå i överensstämmelse med vad man tror att barnet är kompetent att berätta. Detta innebär motsatsvis att ett barns berättelse ska ifrågasättas om barnet förklarar andras beteenden med ord och begrepp som det rimligen inte kan ha erfarit. De av HD formulerade kriterierna anger hur en berättelse bör vara utformad för att anses som trovärdig. Däremot framhålls inte at den juridiska bedömningen även bör innefatta en värdering av små barns kompetens att berätta och förutsättningar at interaktivt producera en juridiskt trovärdig berättelse.

\section{Teoretiska utgångspunkter}

I den här studien utgår jag ifrån följande teoretiska ramar. O rd har olika meningsbärande referenssystem beroende av vem och $\mathrm{i}$ vilket sammanhang de blir sagda. Olika ord signalerar olika mentaliteter, olika sätt att se på saker och ting. Dessutom använder olika diskurser olika typer av uttryck i tal om och beskrivningar av fenomen, vilket i sin tur påverkar den pågående interaktionen (Bakhtin, 1986). Det här betyder att olika aktiviteter där människor interagerar med varandra innehåller olika språkuttryck och varje institutionell, samhäl lelig diskurs utvecklar sin speciella typ av språkanvändning. När barnet i polisförhör ska berätta om ett eventuellt sexuellt övergrepp konfronteras barnet med det juridiskt institutionella perspektivets krav och villkor för språkanvändning. Det gäller då både ordval, krav på hur berättel sen ska vara utformad och de intervjutekniker polisen använder sig av. Dessutom ska barnet i polisförhör interagera i en för dem okänd polisiär miljö. Berättel ser om sexuella övergrepp kan därför förstås som en produkt åstadkommen utifrån den sociala process som uppstått mellan polis och barn i en specifik institutionell miljö. 
En central del i Vygotskys teoretiska utgångspunkt (1978) är tanken att barn lär sig begrepp först genom interaktivt samspel. Därefter internal iseras begreppen och bearbetas intrapsykiskt. Utifrån denna teoretiska utgångspunkt kan det vara svårt för barn som inte internaliserđt det juridiska språkbruket att ge adekvata svar på polisens frågor.

\section{Tidigare forskning}

Forskning har visat att barn är mer kompetenta än vi tidigare anat (Bruner and $\mathrm{H}$ aste, 1987). $0 \mathrm{~m}$ kompetens definieras som barnets förmåga at skilja mel lan verklighet och fantasi så visar forskningsresultat att små barns kognitiva kompetens är ganska väl utvecklad. Dessutom har barn redan från ca 2 års ålder en förmåga att dra slutsatser kring vad andra kan tänkas mena och de kan också använda sådana slutsaser $i$ en dialog (Bruner och Haste,1987). De kan al Itså klara att bearbeta ganska komplexa kognitiva frågeställningar (Reznick och Kagan, 1982) vilket medför att barn i ganska unga år har möjlighet att skilja på vad som är en reell situation och vad som är en fantasiprodukt.

Barnens förmåga att producera en berättelse om sexuella övergrepp påverkas av hur det sociala samspelet utformas mellan dem och polisen. Det här innebär att olika förhörsledares intervjustrategier och intervjustilar påverkar barnets möjligheter att berätta, oavsett barnets kognitiva kompetens (Saywitz och Snyder 1993; Sternberg m.fl.,1995).

Barnen är också själva aktivt inblandade i att försöka skapa mening i den sociala verklighet de interagerar i och möjligheten till påverkan, manipulation och upplevelse av tvång från de människor de interagerar med är en realitet att förhålla sig till när trovärdighet ska tolkas (C eci \& Bruck, 1993). Det betyder att om barn känner sig tvingade att berätta något kan de påverkas till att säga något som inte är rätt men som de tror interaktionspartnern förväntar att de ska säga. Kvalitén på interaktionen mellan polis och barn blir alltså avgörande för barnets möjligheter at berätta en juridiskt trovärdig berättelse.

Tyvärr saknas fortfarande till räcklig kunskap om och förståelse för på vilket sätt den sociala kontexten, där teknikerna används, påverkar utfallet av en intervju (t.ex. Fivush och Shukat, 1995; Lamb m.fl, 1995; Wal ker, 1993).

Förutom ovannämnd a påverkansfaktorer är förhål landet mellan barns ålder och minne komplext och påverkar också utfallet av en intervju. Barnen har en grundkompetens at återge minnesupplevel ser och deras förmåga att återge informativa och längre berättelser utvecklas allteftersom de blir äldre. Det gäller även deras förmåga till att beskriva komplexitet i skeenden (Davies, $\mathrm{m} \mathrm{fl}$, 1989; Flin m. fl, 1992 and Saywitz, 1987). Forskare uttrycker i allmänhet att små barn förmår återge kortare redogörelse av sina erfarenheter jämfört med äldre barn och vuxna men att berättelsen ändå kan vara helt korrekt (till exempel Goodman \& Reed, 1986; Johnson \& Foley, 1984; Marin m.fl 1979; O đes \& Shrimpton, 1991). Barn gömmer precis som vuxna efter hand information de har fått (Flin $\mathrm{m} \mathrm{fl,} \mathrm{1992)} \mathrm{och} \mathrm{när}$ de ska återkalla minnesupplevelser så kan utelämnande av information från små barn bli ett speciellt problem eftersom deras 
återgi vningar oftast är korta och därmed informativt begränsade (Lamb m.fl 1995).

Sammanfattningsvis innebär forskningsresultaten att barn över tre år har förmåga att minnas om de blivit utsatta för sexuella övergrepp och de har kommunikativ kompetens att berätta om det. Förmågan till att berätta mer komplext ökar under förskoleåren. Små barn kan alltså betraktas som helt kapabla att ge användbar information under förutsättning att de intervjuas på ett kompetent sätt (Lamb, m.fl, 1994). Flera forskare understryker dessutom nödvändigheten av en realistisk medvetenhet om barns kapaciteter och sätt att uttrycka sig på hos de förhörsledare som ska intervjua barn. Det är en förutsättning för att barnen ska fås att berätta på ett kompetent sätt (Lamb m.fl., 1995).

\section{Barns berättelser om sexuella övergrepp}

Hur hanterar då barn den förhörssituation där de förväntas berätta om de varit utsatta för sexuella övergrepp eller inte? För att få kunskap om detta har jag bearbetat polisförhören med de förskolebarn ( 2-7 år) som ingår i projektets datamaterial (totalt 54 stycken). Jag har gjort kvantitativa och kvalitativa analyser av de videoinspelade och transskriberade polisförhören. I resultatredovisningen används begreppet sexuella övergrepp för al la de sexuella övergreppsbeteenden som de aktuella barnen tros ha varit utsattaför.

\section{Transkriptionskonventioner}

Alla namn på de inblandande har avidentifierats och $\mathrm{i}$ artikeln anges polis med $\mathrm{P}$, och målsägaren (förskolebarn) med F. Punkter .... betyder att ord uteslutits som bedömts oväsentliga för det som exemplet ska visa. Vid exemplen anges sidnumret i transskriptionen av intervjun inom parentes ( ). Icke verbala beteenden anges på höger sida av exemplen.

\section{Resultat}

\section{Kvantitativ analys}

Det 54 förskolebarn som ingår i projektet var inom åldersintervallet 2-7 år (tabell 1). Medelåldern var ca 5 år.

Redan i tidig ålder blir barn videoförhörda av polisen, 13 barn var alltså 3 år eller yngre när de förhördes.

Tabell 2 visar vilken typ av relation barnen hade till de misstänkta förövarna. $\mathrm{Ob}$ servera att här räknas antal barn och inte antal enskilt misstänkta. Det innebär att en misstänkt kan räknas flera gånger om han eller hon misstänks ha begått brott mot fler än ett barn. Totalt var det 56 personer som var misstänkta för övergrepp.

Det är endast 1 barn som misstänks varit utsatt för sexuellt övergrepp av en för henne okänd vuxen person och mestadels är det barnens nära anhöriga som blir misstänkta för sexuella övergrepp (40 stycken). Det är framförallt de biologiska papporna som anklagas men också andra närstående släktingar.

I polisförhör förväntas barn som varit utsatta för övergrepp avslöja intima detaljer om personer de är i beroendeställning till. Den beräkning som gjordes på antal ord som polisen och barnen använde under de 54 polisförhören visade att barnen använde 23 procent, polisen 73 procent och övriga (mo- 


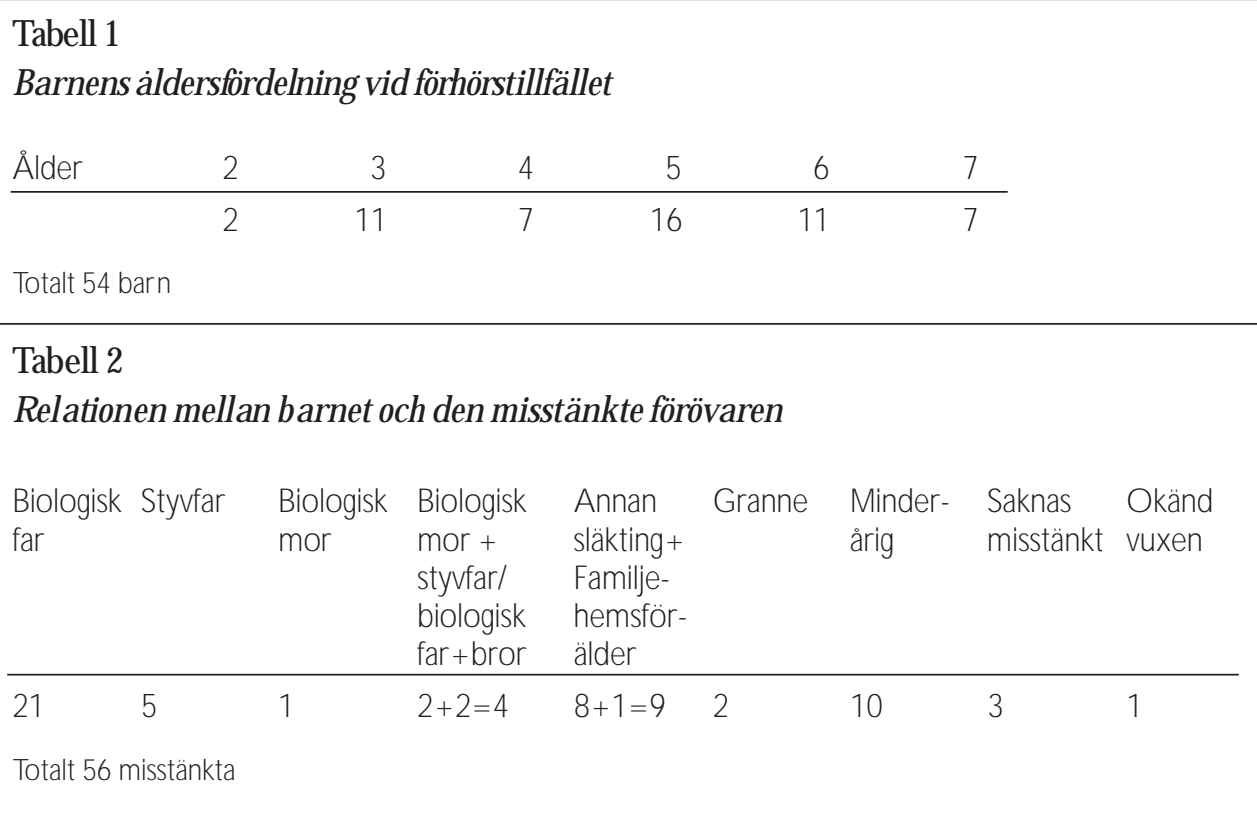

der, syskon el ler ytterligare en polis) 4 procent av talutrymmet.

\section{Kvalitativ analys}

För att närmare förstå hur och om barnen berättar eller förnekar att övergrepp skett mot dem gjordes en berättelse analys av deras polisförhör. Fyra olika former av berättelser utkristalliserade sig: barn som genomgående berättar alternativt förnekar men också barn som fragmenterat berättar eller förnekar. Barn som genomgående berättar eller förnekar övergrepp förmedlar igenom hela förhöret tydligt, klart och utan tvekan om övergrepp skett eller inte. En fragmenterad berättelse är när barnen någon gång under förhöret berättar om övergrepp men ocksåtycks ändra berättel sen genom att exempelvis uttrycka att de inte kommer ihåg eller inte vet om de varit utsatta. När barnen fragmenterat förnekar innebär det att de inte berättar om något över- grepp överhuvudtaget utan förmedlar att ingenting hänt, samtidigt som de också kan säga att de inte vill berätta, inte kommer ihåg om något hänt, eller har en hemlighet med vuxna som de inte vill berätta för polisen.

I tabell 3 kan vi se att 15 av de 54 barnen klart berättar hur och att övergrepp skulle ha utförts mot dem. I förhör med 14 andra barn återges fragmenterade berättelser om övergrepp. Det var 17 barn som tydligt och direkt uttalade att ingen hade utsatt dem för övergrepp och 8 barn förnekade fragmenterat.

Av de 29 förskolebarn $(15+14)$ som berättade genomgående eller fragmenterat var det totalt sex barn som fick sina ärenden prövade av domstol och två av de åtalade förnekade brott. Av de två förnekarna frikändes en och den andre fälldes för övergrepp. Det var 9 barn i gruppen med klara berättelser som misstänktes ha blivit utsat- 
Tabell 3

Barn ens berättel ser om eventuell a övergrepp

\begin{tabular}{rrrrr} 
Misstänkt & $\begin{array}{r}\text { Genomgående } \\
\text { berättelse }\end{array}$ & $\begin{array}{r}\text { Fragmenterad } \\
\text { berättelse }\end{array}$ & $\begin{array}{r}\text { Genomgående } \\
\text { förnekande }\end{array}$ & $\begin{array}{r}\text { Fragmenterat } \\
\text { förnekande }\end{array}$ \\
\hline
\end{tabular}

Minderårig

0 känd för barnet

Morfar/Farfar

Föräldrar

A nnan närstående

Granne

Saknas misstänkt

Antal misstänkta
9

1

1

3

1

15

14

1

3

$8 \quad 13$

2

1

17

8

ta av minderåriga men beräkningen tydliggjorde också att barn har en tendens att berätta eller förneka fragmenterat i större utsträckning när de misstänkta är nära anhöriga till dem. Exempelvis var de flesta misstänkta i den fragmenterade berättargruppen och genomgående förnekargruppen nära anhöriga till barnen. Det samma gäller de barn som fragmenterat förnekade övergrepp.

Utifrån ett juridiskt perspektiv kan en berättelse inte anses trovärdig om barn förnekar mer eller mindre direkt att övergrepp skulle ha skett mot dem. Däremot kan det synas angeläget att försöka förstå vad och varför 13 barn som berättade genomgående och fragmenterđ inte fick sina ärenden prövade av domstol. Hur samproducerade dessa förskolebarn och intervjuande poliser berättelser om sexuella övergrepp? Vid en närmare analys visade det sig att dessa 13 barn genomgående hade svårigheter att tillsammans med polisen konstruera sammanhängande och detaljrika berättelser under förhören. N edan följer en belysning av möjliga förhörskomplikationer för de ovan nämnda 13 barnen. Berättelseprocessen gestaltas genom Karins, Livs och Pias förhör.

\section{A symmetrier i polisförhör med barn}

Polisförhöret kan förstås som ett komplext dynamiskt sampel mellan polis och barn där barnet hamnar i en ojämnlik relation i förhåll ande till polisen men ocksåtill den institutionella miljö polisen representerar. Det är något vi kan hitta i flera institutionella samtal där den professionella har som uppgift att producera ett speciellt resultat med intervjun (se exempelvis C ederborg, 1997; Linell, 1990). A symmetrier i polisförhör med barn blir problematiskt eftersom det kan innebära att barnen inte inser betydelsen av sina utsagor och de kan få svårt at hävda sig inför myndighetspersoner (Diesen, 1996).

\section{Barn vill inte berätta}

I ett och samma polisförhör kan barn komma att förmedla olika bilder kring vad de kan eller inte kan ha varit med om. Dessut- 
om kan barn vägra att berätta vad som hänt, och hur det hänt vilket kan få till följd att den förhörande polisen blir den som konstruerar historien om barnets övergrepp. Barnet blir då den som kommenterar och ger synpunkter på polisens version. Enligt Diesen (1996) kan den typen av frågeteknik innebära att utsagan från mål sägaren får ett lågt bevisvärde. Polisförhöret med Karin, 6 och ett halvt år vid förhörstillfället, är en beskrivning av detta. Karins mamma har tidigare informerat polisen om at Karins pappa ringt henne och berätat att han vidrört flickan i underlivet. I de följande exemplet frågar polisen om Karin funder đt på om detta med pappan kan hända igen. Karin sitter i exemplen 1-4 i hörnet av en soffa och polisen sitter vid sidan om i en fătölj. Dehar i följande exempel ögonkontakt med varandra.

\section{Exempel 1 Karin (sid 9)}

\section{P:Tänk om det händer igen då \\ F: Det tror jaginte at det gör \\ P: D et gör det inte. Varför tror du inte det då? \\ F: J ag har sagt åt pappa đt han inte ska göra så}

På ett indirekt sätt har nu polis och Karin kommit fram till att något har hänt mellan flickan och pappan och att det enligt Karin förmodligen inte kommer att hända igen. Hon talar om något som hänt utan att hon direkt, detaljrikt eller sammanhängande redogör för själva händelseförloppet. Eftersom Karin är fåordig och bestämd $i$ att inte ge några detaljer så tar polisen, via sina frågor och egna tolkningar om ett tänkbart händelseförlopp, kontroll över ämnesvalet. Polisen blir den som styr vad som ska sägas och hur berättelsen ska utformas.

\section{Exempe 2 Karins berättelse (sid 11)}
P: Vart du literädd?
Karin tittar ner i knät
F: Mm
Karin tittar på polisen
$P$ : Det vart du.
F: Mmm
P: Hade du somnat när det hände?
$\mathrm{F}: J \mathrm{a}$
Karin tittar ner

Det är fåordiga svar som Karin ger men hon tillstår att hon blev rädd när hon vaknade och märkte vad som pågick. Det är polisen som inför ett emotionellt begrepp, rädd, via en ledande fråga. Exemplet ger en bild av flickans upplevelse av faderns övergrepp även om det är polisens tolkning av möjlig upplevelse som Karin bekräftar med sitt »mm«. Utifrån ett polisperspektiv kan förhörstekniken vara ett sätt för polisen att visa omtanke om barnet, att rädda flickan från den sociala kränkning det skulle kunna innebära att avslöja sin pappas socialt nedsättande beteende mot henne. Utifrån ett juridiskt perspektiv innebär det att Karin inte återger en egen version.

Längrefram i intervjun återkommer polisen till varför pappan gjorde det han gjorde och hur han gjorde utan att flickan förmås at exakt klargöra vad det var pappan skulle ha gjort.

\section{Exempel 3 Karins berättelse (sid 15)}
P: Tror du att han, tror du att pappa gjorde det här när han lågoch sov så att han inte riktigt visste något eller var han vaken tror du? 


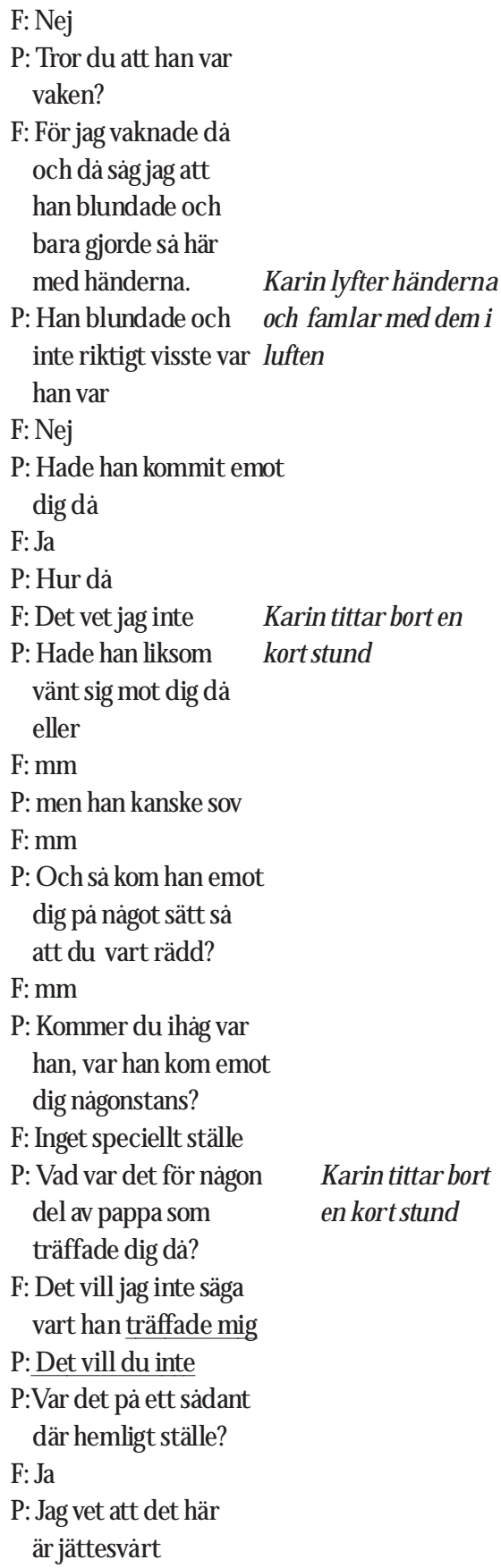

Det är polisen som formulerar beskrivningar kring vad som skulle kunna ha hänt mellan flickan och pappan. Karin vill inte berätta. För at få fram detaljer ställer han ledande frågor utifrån de tolkningar han gjort av händelseförloppet. Karin är bestämd i sina svar, hon utvecklar inte var och hur pappan tog på henne och därmed blir återigen inte händelseförloppet detaljerat och tydligt beskrivet av henne. Polisen visar en inkännande sympati med flickan när han säger att han förstår att det är jättesvårt at berätta vad pappan skulle ha gjort mot henne.

Det är som en genomgående trend i förhöret med Karin att polisen »ägger orden i munnen« på henne. Det följande exemplet kan tjäna som ytterligare belysning av den svårighet det är för polisen att få Karin att beräta om det övergrepp som fadern misstänks ha utfört. Flickan tittar till en början rakt fram och kliar sig i ögat.

\section{Exempel 4 Karins berättelse (sid 22)}

P: och så vaknade du
av att pappa rörde dig
F: mm
P:och rörde dig på ett
ställe som du inte vill
berätta om?
F: Ja (.) Fast när jag sover Karin tittar på
hos pappa en gång till polisen
dåskajag ha trosor
på mig
P: mm det tror jag
F: mm
P:O ch sedan pratade du
med pappa på morgonen
och sa att det där făr inte
hända igen?
F: mm
P: 0 ch då sa han att jag
ska försökalåta bli?
F: M M


F: Har det här varit mer än en gång?

F: Nej det var bara en gång

$P: D$ et har bara varit en gång

F:Ja

P: N u skajag, nu skajag säga rakt ut vad jag tror,

F: Vad sa du?

P:N u ska jag säga rakt ut vad jag tror eftersom du inte säger allt till mig så tror jag att pappa rörde dig mellan benen.

$\mathrm{F}: \mathrm{M} \mathrm{mm}$

P. Var det så?

$\mathrm{F}: \mathrm{M} \mathrm{mm}$

Karin tittar bort.

Det blir polisen som uttalar vad som kan ha hänt, men Karin säger å andra sidan inte emot honom. Hon är noga med att inte uttala exakt vad som hänt, istället berättar hon hur hon tänker agera nästa gång hon ska sova bredvid pappan. Indirekt har polisen tolkat och fătt fram en berättelse om sexuelt övergrepp vilket underförstått innebär att något övergreppsliknande kan ha hänt när flickan var på besök hos pappan. Modern har ju också berättat att Karins pappa inför henne har erkänt övergrepp på flickan. Utifrån polisens perspektiv blev Karin inte socialt hotad under förhörssituationen men berättelsekonstruktionen blev inte tillräckligt tillfredsstäl lande för det juridiska systemet eftersom åklagaren inte ansett att brott kan styrkasi Karinsfall.

\section{Barns detalj beskrivningar}

I den här typen av ärenden är det ju oftast inga vittnen inblandade och därför blir det extra betydelsefullt utifrån rättsäkerhetssynpunkt att barnet som mål sägare förmår att berätta en juridiskt hål lbar version av ett eventuellt övergrepp. Barnet har i förhöret at uppge genital a detaljer om det eventuella övergreppet. Saywitz et. al (1991) kom i sin studie fram till att barn hade svårt att prata om genitalia när de fritt ombads att berätta och även om anđomiska dockor användes. Det var när specifika, ledande frågor ställdes till barnen som majoriteten av barnen i hennes experiment avslöjade att de varit utsatta för genital beröring. Livs förhör kan tjäna som belysning på detta. Hon är 5 år och 5 månader vid förhörstillfället och lever med både sin biologiska mamma och pappa. Hon berättar fragmenterat om övergrepp vilket betyder att hon berättar i omgångar vad pappan skulle ha gjort mot henne men hon säger också jag vet inte, jag kommer inte ihåg osv när polisen vill ha detaljer. Hennes berättelse präglas av att hon förnekar, berättar, förnekar igen, för att till slut återigen berätta att något övergreppsliknande har hänt henne när hon har varit tillsammans med biologiskafadern.

Den kvinnliga polisen tar som hjälpmedel fram två dockor, en pojk- och en flickdocka som Liv tycks uppskatta att leka med. Liv tar exempelvis på dockorna kläder och anmärker på att kläderna är för små. Via sina frågor tycks polisen undersöka vilken kroppsuppfattning Liv har genom att efterfråga en beskrivning av dockans underliv. Flickan sitter i soffan och polisen sitter bredvid.

\section{Exempel 5 Liv (sid 18)}

\begin{tabular}{|c|c|}
\hline $\begin{array}{l}\text { P:Vad är det för någon- } \\
\text { ting som är där bak? } \\
\text { F: Stjärten }\end{array}$ & $\begin{array}{l}\text { Liv sätter på } \\
\text { dockan strumpor, } \\
\text { polisen pekar på } \\
\text { dockans underliv }\end{array}$ \\
\hline med den? & \\
\hline
\end{tabular}



F: Jag vet inte
Liv lutar sig mot
$P$ : Ser du inte att det soffansrygg
är bak och fram, det
här är ju stjärten.
Likadan nästan du
F:Ja
$\mathrm{P}:$ Vad gör man med hålet
da, vad gör man där?
F: Jag vet inte
$P$ : Det vet du inte
$\mathrm{F}: \mathrm{Nej}$

Polisförhöret i sigär oftast en ovanlig och ny situationsupplevel se för barnet. Barnet förväntas kunna beskriva och tala om personliga intima detaljer som kan vara tabubelagt och lite svårt att prata om. Här visar Liv tecken påatt hon inte vill prata om eller inte tycks känna till underlivets olika delar och vilka funktioner de kan ha. I exempel 8 däremot kan Liv peka på sin egen kropp var pappan skulle ha petat när polisen efterfrågar en specifik beskrivning.

\section{Barnperspektivi relation till vuxenperspektiv}

I Livs förhör refererar polisen till moderns tolkning av övergreppet mot flickan. Modern polisförhördes före Liv. Här har Liv och polisen ögonkontakt.

\section{Exempel 6 Liv (sid 21)}
P: Men då måstejag tala
om för dig vad din mamma sa
F:Ja
$P: A t t$ du var röd i stjärten
långt in i stjärten så du påcykeln
kan inte ha gjort digilla
F: Nej Liv skrattar generat
$\mathrm{P}:$ Du måste ha gjort
digilla pånågot annat sätt
F: Påtvålen
P: Påtvålen
F:Ja
$P:$ Vad har du gjort med den då?
F: Tvättat mig
$P:$ Själv, mm
Liv lutar sig
F:Ja
P: hmm. Du blir lite ledsen när mamma ska bakåt tittar på åka och jobba säger hon polisen. Liv sätter tummen i och du får vara kvar hemma
F:Ja
P: Varför blir du det, varför?
F: Därför
Liv viskar

Modern misstänker att fadern har utsatt Liv för sexuellt övergrepp. Polisens strategi att rekonstruera eventuellt händel seförlopp genom mammans version av händelseförloppet innebär att Liv har att förhålla sig till först moderns version av händelseförloppet och sedan polisens tolkning av densamma. Det blir två vuxnas versioner av en eventuell händelse som tillåts prägla bilden av vad som skulle ha hänt mellan fadern och henne. $\checkmark i$ vet därför inte om Liv skulle beskrivit refererade situation på ett annat sät om inte de vuxnas version fătt styra berättelseprocessen. Den vuxenorienterade förförståelsen av händelsen innebär uppkomsten av en asymmetri mellan barnperspektiv och vuxenperspektiv vid rekonstruktions processen. Barnet som är i en beroende ställning, i det här fallet till både modern, fadern och polisen, tenderar att hamna i konflikt mellan sina egna förståelsegrunder för vad som hände i förhållande till de vuxnas. Det kan innebära att barn blir tveksammatill sin förmåga att berätta om förloppet.

I det följande exemplet stäl ler polisen en direkt fråga till Liv om pappan har »pillat«i 
hennes stjärt. Polisen lutar sig fram mot flickan som i sin tur lutar sig bakåt i soffan.

\section{Exempel 7 Liv (sid 23)}

\begin{tabular}{|c|c|}
\hline $\begin{array}{l}\text { P: O ch då säger jag } \\
\text { samma fråga. Har } \\
\text { pappa pillat dig i stjärten }\end{array}$ & \\
\hline $\mathrm{F}: \mathrm{Ja}$ & \\
\hline$P: V a$ & \\
\hline F: Jag vet inte & \\
\hline $\begin{array}{l}\text { P: J a säger du, men jag } \\
\text { vill veta antingen så } \\
\text { vet du eller så vet du inte, } \\
\text { det är synd, vi kan ju inte } \\
\text { säga att pappa har gjort }\end{array}$ & \\
\hline $\begin{array}{l}\text { något som han inte har } \\
\text { gjort. }\end{array}$ & $\begin{array}{l}\text { Polisen lägger sin } \\
\text { hand på flickans }\end{array}$ \\
\hline F: Jo det har han & mage \\
\hline
\end{tabular}

Liv svarar ja på frågan om pappa har »pill at« i stjärten och polisen tycks bli förvånad av Livs tydliga ja svar och reagerar med att efterfråga ett förtydligande kring vad som faktiskt hänt. Liv verkar då tveksam till om pappan har vidrört henne eller inte. $G$ enom att säga att det är synd om fadern om han blir anklagad för något han inte gjort intar polisen ett fadersperspektiv, kanske för att testa om Liv verkligen står fast vid sin berättelse även om det blir synd om fadern. Liv har att perspektivisera sin berättelse utifrån pappans eventuella svårigheter i samband med att han skulle anklagas för övergrepp. Liv ger ett tydligt svar, pappan har begått en övergreppshandling mot henne. Förhörstekniken, att spela på barns skuldkänslor, antyder att det finnsen uppfattning inom juridiken att barn kan förstås som trovärdiga om de berättar om övergrepp som utförts av en person det kan bli synd om när anklagelsen avslöjas. Strategin kan också förklaras av po- lisens frustrerande situation när de inte lyckas få barnet att berätta en juridiskt hållbar berättelse i fall där de misstänker att övergrepp faktiskt har skett. Liv visar att hon står för sin berättelse trots risk för skuldkänslor mot pappan.

\section{Barns svårigheter att berätta}

Livs berättelse har hitintills varit otydlig vad gäller detaljbeskrivningar. Hon ger i nästa exempel en möjlig förklaring till det »det är svårt att säga«. D etta är en information som ytterligare belyser komplexiteten i polisförhör om sexuella övergrepp med barn. Liv får också förståel se från polisen för sina svårigheter. Frågan är om hon uttrycker att det är svårt att hitta de rätta orden eller/och berätta om detta socialt känsliga ämne. Liv försöker igen, efter polisens förståelse, berätta vad det var som har hänt. Liv lutar sig här mot ryggstödet och tittar först inte på polisen.

\section{Exempel 8 Liv (sid 25)}

F: Det är svårt att säga
P: Det tror jag var riktigt
sagt
F: Svårt
P: Ja det är jättesvårt,
jätttesvårt är det
F: Pillar i hålet $\quad$ Liv tittar mot pol isen
P: Va
F: Pillar i hålet
P: M m
P: Vet du vad jag tyckte
du sa, pillar i hålet
såtänkte jag, det är
väl du som sitter och
pillar i håret nu då
F: Nej
P: Pillar i hålet, var finns


det något hål då?
F: Här bakom
P: Nu får du visa mig, vilket hål. Får jag se
$F$ : Här bakom där
$P: I$ det hålet
F:Ja
$\mathrm{P}:$ Vem pillar där?
F:Jag vet inte
$\mathrm{P}$ : Tittut vem pillar $\mathrm{i}$ det hålet då? A sch du kan berätta för mig nu så vi får sluta så vi får gå in och äta kex och hämta någon grej i stället,

F: isch

P: Isch ja vad svårt det Polisen lyfter dockan är från flickansögon.

F:Ja

P: Fast det är snart gjort va. Kom nu så snackar vi om det så går vi och hämtar litet sen
$\mathrm{F}:$ Jag vet inte
Liv tittar på dockan
$\mathrm{P}$ : Men vilket hål menar du?
F: Här bakom
P: O ch vem pillar här bakom?
F:Pappa kanske Liv tittar ner
P: Pappa kanske ja, vad pillar han med då?
F: Med fingret Liv tittar mot polisen

Det här är den del av förhöret där övergreppsbeskrivningen blir tydligast. $H$ är använder Liv ordet hålet för att beskriva var pappan petade och pekar också var hålet finns. (Jämför exempel 5 där Liv inte kunde beskriva underlivets olika delar på dockan). Det tycks som om polisen använder sig av en skämtsam och konkret frågestrategi för att försöka få Liv att bli tydlig med var pappan skulle ha tagit på Liv. När flickan ska berätta vem som »pillat«, gömmer hon sig bakom dockan. Sett utifrån ett juridiskt perspektiv tycks polisen ha ambitionen att få fram en tydlig juridiskt hållbar berättelse vilket kan förklara den muta som Liv erbjuds för att upprepa ytterligare en gång var och vem som «pillar «.

Efter den här sekvensen får Liv också frågor om var övergreppet skedde och Liv återger då att det skett »i det stora rummet « och hon får också redogöra för hur det känns när pappa pillar »D et svider litet«. I Livs andra förhör framkommer också fragmentariska bilder av vad Liv skulle kunnat havarit med om men otydligheter i berättelsen kvarstår. $H$ on ger inte några längre detaljbeskrivningar eller förtydligar det eventuella skeendet och dessutom pendlar hon i sin version om vem som skulle ha orsakat sveda. Ena gången är det pappan, andra gånger är det tvålen.

Forskning har visat att barn är aktivt inblandade i att försöka skapa mening i dialoger och de påverkas av de människor de interagerar med (Ceci \& Bruck, 1993). Förutom att det är känsligt och svårt att berätta om övergrepp föreligger en risk att Liv blir tveksam till om de tidigare versionerna hon lyckats avge inte godtagits av el ler är möjliga att förstå för polisen. Detta kan i sin tur vara en delförklaring till att hon ger vaga och tveksamma versioner av vad som hänt när hon förväntas upprepa berättelsen.

\section{Barns hantering av vuxenorienterade frågetekniker}

Det finns inga klara riktlinjer kring hur förhör med barn som mål sägare ska genomföras, förutom de mer generella som regleras i 
RB 23 kap eller FUK 15- 19 §§, men juridiska tolkningsramar tycks ha till följd att frågetekniker blir vuxenorienterade vilket kan göra frågorna svåra för barn att svara på. Dettakan i sin tur leda till att små barn ändrar berättelser el ler omformulerar dem snarare än att de blir mer stringenta. I det följande exemplet så tittar Liv mot polisen som sitter bredvid henne i soffan.

\section{Exempel 9 Liv (sid 29)}

\author{
P: Hur har det känts då? \\ F: D et svider litet Liv tittar ner \\ P: Då eller nu, när pappa \\ pillar? \\ $\mathrm{F}: \mathrm{Nu}$ \\ P: Men hur känns det \\ när pappa pillar då? \\ F: Svider det, det var \\ tvålen. \\ Liv tittar kort mot \\ polisen \\ :Var det tvålen nu \\ igen, nu får du be- \\ stämma dig, antingen \\ är det tvålen eller också \\ har pappa pillat? \\ F: D et är tvålen, jag L Liv ler mot polisen \\ bara skoja det är tvålen
}

När polisen uttalat att det är antingen tvålen eller pappan som orsakat svedan kan det tyckas som om Liv återtar sina tidigare versioner av övergreppet. Polisens förväntan om tydlighet kring när det svider, vem eller vad som orsakat sved an eller när polisen uttrycker att det bara finns en sanning antingen det ena eller det andra kan det ha till följd att flickan ändrar tidigare versioner. Det kanske inte finns ett svar att få fram, det kan vara så att det är både tvålen och pappan som orsakar svedan. Utifrån ett barnperspektiv kan krav på upprepade förtydliganden bli för komplicerat för barn att hantera vilket kan resultera i att de blir osäkra och ändrar tidigare versioner av en berättelse.

Det följande exemplet visar på ytterligare en frågestrategi för att få fram vad som är sant respektive falskt i barnets berättelse, något som är av avgörande betydelse i den juridiska kontexten. Sekvensen är från det andra förhöret med Liv och polisen undrar om Liv minns att de pratade om pappa sist de sågs. Liv tittar ner.

\section{Exempel 10 Liv (sid 36)}

P:....Minns du att vi

pratade om pappa sist?

F:la

P:M m och vet du vad det är om att man talar sanning det vet du vad det är?

F:Ja

$\mathrm{P}: 0$ ch vet du vad det är om man intetal ar sanning?

F: Nej

$\mathrm{P}:$ Vad är det? $\mathrm{M}$ an Liv tittar kort mot brukar säga att man polisen kan tala sanning eller ljuga. Talar du sanning när du berättade att pappa hade gjort någonting?

$\mathrm{F}: J \mathrm{~J}$

$P:$ Det var sanning?

$P: J a$

P:För han skulle ju bli så himla ledsen om det inte var sant va

F: Nej

$\mathrm{P}:$ Kommer du ihåg vad du berättade att pappa hade gjort då?

F: Nej

Forskning har visat att barn kan processa ganska komplexa kognitiva frågeställningar 
(Reznick och Kagan, 1982) men också att barn kan påverkas till att säga något som inte är rätt när de har ambitionen att tillfredsställa vad de tolkar som den vuxnes svarsförväntningar (C echi och Bruck, 1993). Här svarar Liv att hon vet vad sanning är men inte vad lögn är. Polisen förklarar för henne och Liv är tydlig med att hon talat sanning. Problemet uppstår när polisen för in en emotionell aspekt om att pappan skulle kunna bli ledsen om hon berättade en lögn. Under förhöret har flickan berättat, dock inte sammanhängande, at pappan begått någon form av övergrepp mot henne. Livs svar testas av polisen genom införandet av en känsloaspekt. Det kan förstås som att barnet utsätts för ett emotionellt spel för att få fram om hon ljuger eller inte. Liv reagerar med att säga att hon inte kommer ihåg vad hon tidigare berättat.

Den här studien visar (se tabell 3) att barn berättar och förnekar mer fragmenterat om den misstänkte är en närstående person som barnet står i beroendeställning till. Det är en person som skulle kunna bli ledsen för att barnet berättat något tillsynes ofördelaktigt om honom eller henne. Genom att föra in en emotionell aspekt för att få flickan att berätta blir svaret från flickan problematiskt att tolka. Hon säger sig ju nu inte komma ihåg vad hon tidigare berättat om pappans agerande. Det finns alltså en risk at domstol arnas högt ställda beviskrav kan få polisen att formulera frågor som försvårar för barnet att åstadkomma en juridiskt hållbar berättelse.

Efter den här sekvensen får Liv ytterligare detaljfrågor kring var pappan petade, vad hade pappa på sig, var någonstans i lägenheten skedde petandet och vad petade han med. Liv får också frågor om utseendet på pappans könsorgan och om hon vidrört det, vilket hon säger att hon gjort. Likaså frågar polisen om det kommit något vätska från faderns könsorgan. Därutöver ska Liv svara på hur hon reager at när fadern vidrörde hennes könsorgan. Följande sekvens belyser hur barnet hanterar krav på ordagranna đ̊tergivningar av ett kritiskt händelseförlopp. Polisen och Liv sitter i soffan och klär på varsin docka.

\section{Exempel 11 Liv (sid 46)}

P:..Sa du till honom
någonting då?
F: Ja
P:Vad sa du då?
F: Låt bli
P: Jaha vad sa pappa då då?
F: Han sal låt bli
P: Men det var ju du som sa.
F: M m
P:Vad sa pappa då sa jag?
F: Så då sa han
P: Vad sa han?
F: Dåsa han det $\quad$ Liv lutar sig bakåti
P:Att
F:Att jag var lite $\quad$ polfan och tittar på
trasslig, trasslig

Polisen ställer enkla korta frågor som Liv svarar fåordigt på. Utifrån ett juridiskt perspektiv tycks Liv ha svårigheter att tydliggöra vem som sa vad. Vem som är subjektet blir inte tydligt i hennes svar på polisensfrågor. Polisen som efterfrågar tydlighet kring vem som sa vad, belyser återigen förväntningar på att barnet ska återge santingen eller svar « Ena gången ser det ut som hon själv säger »åt bli« andra gången är det pappan som ska ha sagt »låt bli «. Förutom att Livkan ha vissa språksvårigheter styrs frågeställ- 
ningarna av en föreställning om att det finns endast en sanning att återge. Det finns därmed en risk att barnet blir missförstått om hon inte lyckas bli tydlig med vad hon menar. Exemplet skulle faktiskt också kunna tolkas utifrån förutsättningen at det var både pappan och Liv som sa »låt bli « Liv för att hon inte ville att pappan skulle ta på henne och pappan för att få Liv att lăta bli att trassla när han tog $i$ henne. $V i$ vet inte med säkerhet om Livs pappa har begått ett sexuellt övergrepp på henne. Det vi vet är att Liv formulerat något som skulle kunna innebära att ett övergrepp faktiskt kan ha skett och att hon har tendens att ändra sina detaljbeskrivningar när hon utsätts för krav på förnyade reflexioner av händelseförloppet. HD:s riktlinjer för en trovärdig berättelse blir inte uppfyllda och ärendet leder inte till åtal.

\section{Barns språk}

Pia är ytterligare en flicka som berättar fragmenterat om sexuel It övergrepp av sin biologiska far. Hon är 3 år och 7 månader vid förhörstillfället och bor tillsammans med sin mamma och syster. Det är systern, 6 år, som berättat för mamman att pappan skulle ha utfört sexuella övergrepp på Pia när syskonen vistades hos pappan över en helg. Vid analysarbetet av pol isförhöret synliggörs att Pia har svårigheter att verbalt beskriva vad som har skett. Efter at först ha förnekat att någon gjort någonting med hennes stjärt så tillstår hon att hon haft ont. Detta sker efter att polisen använt förhörstekniken att konfrontera Pia med den berättelse modern givit till polisen. Pia formulerar alltså inte själ v vem som är aktör och vem som har ont i stjärten.
Sett i ljuset av att systern har kunnat berätta om övergreppshändelser på Pia till både mamman och polisen belyser det följande exemplet Pias svårigheter att språkligt tillfred sställa juridikens krav på trovärdiga berättelser. Pia sitter i soffan och tittar ăt sidan, polisen sitter bredvid.
Exempel 12 Pia (sid 7)
P: Vad gjorde han då som var jättedumt då?
F: H an hade han, Pia tittar kort mot hade ont i stjärten polisen sedan ner
$\mathrm{P}$ : Hade han ont $\mathrm{i}$ på dockan
stjärten?
F: Pappa, våran pappa
$\mathrm{P}:$ H ade han ont i stjärten?
F:Ja
P: Hur vet du det?
F: Vet jaginte Pia tittar kort mot
$\mathrm{P}$ : Sa han det då, va? polisen
Du saju att du hade Pia tittar kort mot ont i dinstjärt polisen
F: Hade inte ont i min stjärt
$P: V a$

Forskare har visđ att det kan vara ett speciellt problem att få godtagbar information från små barn när de utelämnar information av händelser och deras återgivningar oftast är korta och informativt begränsade (Lamb m.fl 1995). Utifrån ett juridiskt perspektiv kan den här sekvensen väcka tveksamhet kring huruvida Pia har varit utsatt för övergrepp eller inte eftersom hon inte lyckas tydliggöra vem som har ont, hon eller pappan. Utifrån Pias perspektiv, kan det vara så at hon försöker berätta att det pappan gjort innebar att hon fick smärta i underlivet. Polisen som har att hål la sig till den juridiska tolkningsramen kräver vid två tillfällen spe- 
cificeringar från flickan »Hade han ont i stiärten «. Det tyder på att polisen vill ha ett förtydligande från Pia kring vem som hade ont eftersom hennes tidigare svar skulle kunna vara till hennes nackdel i den juridiska tol kningsprocessen av hennes berättelseproduktion. Pia har ju svarat svårtydligt »H an hadehan, hadeonti stjärten «.

Polisen använder sig av systerns version av övergreppet kanske som ett sätt att få Pia att berätta ytterligare detaljer kring övergreppet. Följande exempel belyser återigen Pias svårigheter att språkligt uttrycka händelseförloppet på ett klargörande sätt. Polisen låter systerns berättelse få gestalta att pappan gjort något med Pias underliv. Det tyder på en förhörsstrategi att få Pia att berätta via systerns mer detaljerade beskrivning av händel seförloppet. Pias svar gör inte sakfrågan tydligare vilket kan förklara polisen önskemål om förtydligande från Pia. Här pysslar Pia med två dockor hon har i knät.

\section{Exempel 13 Pia (sid 9)}

P: Vet du Pia, eller Pia
heter du. Vet du Pia Pia tittar kort mot
att Sussie sa att hon pol isen
såg att pappa petade
digi stjärten
F: Men hon såg inte det
P: Va sa du?
F: Hon såg inte det
P: Hur vet du att hon inte
såg det?
F: Hon såg inte att att
jag, att han har ont i
stjärten
P: Vad sa du nu?
F: Att pappa hade
ont i stjärten
P: Har pappa ont i stjärten?
F:Jahade han
$\mathrm{P}$ : Hur vet du det?
F: Vet jag inte
$P$ : Vem har sagt att pappa har ont i stjärten?
F: Han hade ont hemma hososs
P: Hemma hos er, men du har aldrig ont i stjärten?
F: nej hade jag inte

Vad är det då hon faktiskt säger och hur ska det förstås? Frågan handlar om Pia vet huruvida systern har sett pappan peta i hennes stjärt eller inte. Pia tycks tro att Sussie inte såg vad som hände och via polisens följdfrågor om förtydligande kring vad hon säger blir rekonstruktion än mer otydlig. Utifrån ett juridiskt perspektiv blir exempelvis polisens motfråga om pappa har ont i stjärten besvarad på ett sådant sätt av Pia att det kan uppstå tveksamheter kring om det är pappan som åsamkat henne det onda i stjärten eller om det är pappan som har ont. Förmodligen förmår inte Pia, utifrån retoriska aspekter, uppfylla de juridiska kraven på sammanhängande och detaljerad berättelse trots at både polisen och flickan anstränger sig för att förstå varandras uttalanden. Polisens och barnets perspektiv möts inte, det blir barnets referenssystem i förhållande till polisens.

\section{Diskussion}

Det är aktörer inom det juridiska systemet som har tolkningsföreträde vid avgöranden om barns trovärdighet. Polisen har att uppfylla juridikens krav på att åstadkomma de- 
taljrika, sanna, sammanhängande och tydliga berättelser om sexuella övergrepp i förhör med målsägaren. Frågan som den här studien har belyst är små barns asymmetriska position i polisförhör och barnens svårigheter att tillfredsställa det juridiska systemet. Studien visar att det finnsen risk att de krav som det juridiska systemet ställer begränsar snarare än skapar förutsättningar för barn att berätta om övergrepp.

Små barns ärenden prövas i minimal utsträckning av domstol. När barn förnekar genomgฉ̊ende eller fragmenterat finns ingen berättelse att ta ställning till för jurister men den här studien visar att det var 13 barn som berättade genomgående e l ler fragmenterat om övergrepp av vuxna men de fick inte hel ler sina ärenden prövade. Eftersom åklagare inte behöver motivera sitt beslut vet vi inte grunderna till varför de inte åtalar. Å klagaren har endast att fylla i en av de 14 rutor som markerar beslut om varför åtal inte ska väckas. Av de ovan nämnda 13 barnen var det 11 ärenden som rubricerades under rubriken »Brott kan ej styrkas« och 2 där rubriceringen var »G ärningen ej brott«.

Den juridiska miljön och den interaktiva process som förhören konstrueras under är avgörande för utfallet av intervjun. Linells (1990) beskrivning om hur mening skapas interaktivt kan exempelvis förklara kontextens betydelse för utfallet av en intervju med barn. Han skriver att en dialog är en interaktiv process som påverkas av den miljö som de agerande vistas i, det vill säga den praktikens förutsättningar. Linell (1990) skriver vidare att det är genom en dialogisk process som sociala relationer uttrycks, reflekteras, och bestäms. Det som blir bety- delsebärande är processat genom både interaktiv- såväl som intra- individuell kommunikation. Det finns alltså en dialogisk relation i polisförhöret mellan vad som skapas och produceras och de förutsättningar som getts till att utföra förhöret (se också A ronsson, 1991).

I förhör är det polisen som tar och ger initiativ och barnet hanterar situationen genom at besvara de frågor som ställstill henne/honom. Polisen och barnet närmar sig och deltar i intervjun från olika positioner vilket bidrar till att de uppfattar och tematiserar olika aspekter av ett och samma ämne. G raumann (1990) har exempelvis uttryckt att dynamiken i en dialog handlar om at försöka få fram sitt eget perspektiv och at få den andra att fortsätta samtalet med den utgångspunkten. Perspektivitet är därför at betrakta som ett interaktivt fenomen och förmågan att ta andras perspektiv är en förutsättning för kommunikation som sådan. Vi kan utgå ifrån att både polis och barn vanligtvis har den kompetensen men de har olika referenspunkter och värderingssystem när de möts på polisstationen. I den här studien visar det sig at små barn kan ha svårigheter att exempelvis besvara frågor som kräver förtydligande om detaljer, el ler att avslöja intima detaljer om sig själva eller misstänkta. Barnens ibland förvirrade, korta el ler ospecifika beskrivningar kan förklaras av den asymmetriska sociala relation som uppstår mellan polis och barn i förhör. Det innebär vidare att små barn har ganska små möjligheter att lyfta fram sitt perspektiv på det som samtalet rör och därmed minskar deras förutsättningar att bli trodda av det juridiska systemet.

Ett exempel påasymmetrisk perspektivi- 
tet är det språkbruk som används vid utformandet av olika frågetekniker. Det juridiska språkbruket har meningsbärande innebörder som polisen känner till, men hur är det för barnet? Polisen är den expert som tillsammans med barnet har att åstadkomma juridiskt trovärdiga berättelser för åklagaren att ta ställning till. I förhöret ska polisen skapa en förståelse för vad som kan ha hänt om något har hänt barnet. Frågestäl Iningarna är utformade utifrån juridiska förväntningar på berättelseproduktion. Det tycks finnas en inbyggd förväntan att barnet ska förstå och kunna besvara dessa frågor utan hänsyn till den asymmetriska situation de befinner sig i. Utifrån $\mathrm{C}$ apps och $\mathrm{O}$ chs (1996) är språket ett strategiskt instrument för att överföra olika innebörder mellan de agerande. C oates et al. (1994) har också uttryckt att de ord som används för att beskriva en handling är de ord som ger mening till det som faktiskt hänt. När barnet inte utgår från samma språkliga och erfarenhetsbaserade referenssystem som polisen kan det ha till följd att barnet inte kan förstå innebörden i polisens frågor och därmed inte heller besvara frågorna på ett för jurister tillfredsställande sätt.

Barn har olika förmågor att berätta men oavsett ålder har barn en ökad möjlighet att berätta om frågeställningarna är förenklade, omgivningen är stödjande och det sociala och emotionella klimatet är till deras fördel (Goodman and Schwartz-Kenney, 1992). Barn påverkas alltså i sin berättelseprocess av de förhörstekniker som används vid förhörstillfället (till exempelvis Saywitz och Snyder, 1993). Den här studien visar att de förhörstekniker som används vid förhör med små barn innebär en förväntan på dem att de ska kunna besvara och ge uttryck för svåra, privata och emotionella upplevelser på ett tydligt, sammanhängande och för det juridiska systemet trovärdigt sätt. Små barn som förmås berätta fragmenterat om övergrepp berättar exempelvis indirekt om övergrepp och då kan det bli polisen som formulerar ett juridiskt trovärdigt händelseförlopp. Ställer polisen frågor med önskemål om förtydligande från barnet, utnyttjar barnets lojalitet med den misstänkte eller formulerar frågor om detaljbeskrivningar så kan det innebära att barnet stappar «sin version av ett eventuellt händelseförlopp.

Barnens deltagarstatus i polisförhör kan beskrivas som ojämnlikt och sett utifrån ett barnperspektiv tycks inte deras förutsättningar att uppnå juridiskt tillfredsställande berättelser alltid tas i beaktande vid tolkningen av trovärdighet. N är ju rister försöker konstruera logiska händelseförlopp för at förstå om och vad som har hänt barnet kan den beskrivning de har at utgå ifrån bygga på utsagor som är baserade på barnets okunskap om begrepps innebörder men också på att de inte erbjudits för dem fördelaktiga förhörsvillkor. Det finns en risk att de ord som barnet väljer oproblematiskt får symbolisera den objektiva sanningen vid åklagarens bedömning av trovärdighet istället för att orden blir belysta utifrån kontextuella, interaktiva och utvecklingspykologiskautgångspunkter.

Utifrån ett barnperspektiv kan alltså samtalstekniker som utvecklats för att uppfylla juridisk stringens ha konsekvensen att barn som utsatts för övergrepp inte kommer till sin rätt i den juridiska kontexten. Därmed kan barns berättelser bli den svagaste länken $\mathrm{i}$ att skapa förståelse för om de varit 
utsatta för sexuella övergrepp. Det här speglar vilken vikt åklagaren lägger vid de riktlinjer som utvecklats inom domstolsväsendet för hur en trovärdig berättelse ska vara konstruerad. Det belyser också hur de juridiska föreställningarna om vilken berättelseproduktion barn förväntas åstadkomma transformeras i polisens förhörstekniker. M isslyckas barnet med att svara och bete sig på ett juridiskt tillfred sstäl lande sätt är det mer att förstå som deras personliga misslyckande än en kritik mot den situation de förväntas hantera när de kommer i kontakt med det juridiska systemet. Med en vuxenorienterad inställning till hur förhör med barn ska tolkas finns det en risk att små barn som varit utsatta för sexuella övergrepp inte blir förstådda av det juridiska systemet och de skyldiga förövarna kan komma att frikännas.

Jag vill tacka Peter Sundström, rådman vid Linköpings Tingsrätt, projektets juridiska expert och rådgivare, för synnerligen värdefulla kommentarer på denna text.

\section{Summary \\ Pre-school children's narratives of sexual abuse}

This study illuminates pre-school children's asymmetrical position in police interviews when sexual abuse is alleged to have occurred. The main purpose of this study isto increase understanding of how children and police officers co-operate when they coconstruct meaning of the sexual abuse in the police interviews. What sort of questions do police officers use in their investigation and how do the children manage to answer these questions in the juridical context in which they are interviewed? The analyses are done from the perspective of the child. The investigation is based on video-taped police interviews with 54 preschool children in one police district in Sweden suspected of having been sexually abused during the period 1986-1995. The main findings are that pre-school children are not believed if they construct a fragmentary narrative about sexual abuse. The study shows that the children are exposed to adult-oriented questions. As the questions are not posed from the perspective of the child they can be said to deny the injured party the opportunity to make his or her voice heard in the legal context. Further, this study shows how the Swedish Supreme Court's recommendations are reflected in the police interviews with children. The implication is that pre-school children are sometimes restrained from telling a narrative about sexual abuse because the strategies for eliciting information do not take into account ways in which children express detailed, concrete and coherent narratives about sensitive private and emotional maters. 


\section{Referenser:}

A ronsson, K. (1991) Social interaction and the recycling of legal evid ence. I C oupland, H. Giles och J. M. W iemann (red.), M iscommunication and problematic talk. Newbury Park: Sage sid 215-243

Bakhtin, M. M . (1986) Speech genreand other late essays. Austin: University of Texas Press.

Bruner, J. och H aste, H. (1987) Introduction. I J. Bruner och $\mathrm{H}$. Haste $\mathrm{M}$ aking sense. The child's construction of the world. London: M ethuen

C ampell, T. W. (1994) Beware the talking cure. Boca Raton Fla: Social Issues Resources Service.

C apps. L och $O$ chs, E. (1996) C onstructing panic. The discourse of agoraphobia. N ew York: Sage

C eci, S. J., och Bruck, M . (1993) The suggestibility of the child witness: A historical review and synthesis. Psychological Bullentin, 113, 403-439

C ed erborg, A-C. (1997) Young children's participation in family therapy. T heAmerican journal of family ther apy 25,1 .

C oates. L., Bavel as Beavin, J. och G ibson, J. (1994) A nomal ous language in sexual abuse trial judgments. D iscourseand Society 5(2) 189-206

Davies, G ., Tarrant, A ., och Flin, R (1989) C lose encounters of the witness kind:C hildren's memory for a simulated heal th inspection. British Journal of Psychol ogy, 80, 415-429.

Diesen, C. (1996) Förhörsteknik. I T. Bring, C. Diesen, L. Schelin, och A. Wilton Förhör. Stockholm; N ordstedts J uridik.

Flin, R., Boon, J., Knox, A, och Bull, R. (1992) The effect of a five-month delay on children's and adults' eyewitness memory. British J ournal of Psychology, 83, 323-326

Fivush, R., och Shukat, J. R. (1995) C ontent, consistency and coherence of early autobiographical recall. I M. S. Zaragoza, J. R. G raham. G ordon, C.N Hall, R. Hirschman, Y.S Ben-Porath (red.). M emory and testimony in the child witness. Thousand $O$ aks, C A :Sage Sid 5-23

Graumann, C. F.(1990) Perspectival structure and dynamics in dial ogues. I I. M arkova och K.
Foppa. The dyn amics of dial ogue. London: Harvester W heatsheaf Sid 105-126

Goodman, G. S., och Reed, D. S. (1986) A ge differences in eyewitness testimony. $\mathrm{L}$ aw and $\mathrm{Hu}$ man Behavior, 10, 317-332

Goodman, G. S. och Schwartz-Kenney, B. M. (1992) W hy knowing a child's age is not enough: Influences of cognitive, social and emotional factors on children's testimony. I H . Dent och R. Flin C hildren as witnesses. Chichester: Wiley

G regow, T. (1996) N ågra synpunkter på frågan om bevisprövning och bevisvärdering i mål om sexuella övergrepp mot barn. Svensk Juristtidning 7, 509-523

Johnson, M. K ., och Foley, M. A . (1984) Differentiating facts from fantasy. The reliability of children's memory. Journal of Social I ssues, 40 , 33-50

Lamb, M. E., Sternberg, K. J. och Esplin, P. W. (1994) Factors influencing the reliability and validity of statements made by young victims of sexual maltreatment. Journal of A pplied Developmental Psychology, 15, 255-280

Lamb, M . E., Sternberg, K. J. och Espl in, P. W. (1995). Making children into competent witnesses. Reactions to the A micus Brief I Psychology, Public Policy, and L aw 1, (2) 438-449

Linell. P. (1990) The power of dial ogue dynamics. II. M arkova och K. Foppa. The dynamics of dial ogue. London: Harvester W heat sheaf.

Loftus, E. (1995) Remebering dangerously. The skeptical inquirer 19 (2) 20.29

M arin, B.V., Holmes, D. L., Guth, M ., och Kovac, P. (1979) The potential of children as eyewitnesses. L aw and -H uman behavior, 3, 295-305

O ates, K., och Shrimpton, S. (1991). C hildren's memories for stressful and non-stressful events. M edical Science and L aw, 31, 4-10

Reznik, J. S. och Kagan, J. (1982) C ategory detection in infancy. I L. P. Lipsett och C. K RoveeCollier (red.). A dvances in infancy research. Vol 2 Norwood, NJ : A blex sid 80-111 Saywitz, K. J . (1987) C hildren's testimony: Age- 
related patterns of memory errors. I S. J. Ceci, M. P. Toglia, och D. F. Ross (red.). C hild victims, child witness: Understanding and improving testimony. New York: Guilford Press. Sid 117-146.

Saywitz, K. G oodman, G., N icholas, E., och

Moan, S. (1991) C hildren's memories of a physical examination involving genital touch: Implications for reports of child sexual abuse. Journal of consulting and clinical psychology, 59, 682-691

Saywitz, K. J., och Synder, L. (1993) Improving children's testimony with preparation. In G . S G oodman and Bottoms (red.). C hild victims, child witnesses: Understanding and improving children's testimony N ew York: G uilford Press Sternberg,K , J., L amb, M . E., Hershkovitz, I., Yudi levitch, L., O rbach, Y., och Wal ker, A. G. (1993). Q uestioning young children in court: A linguistic case study. L aw and $\mathrm{H}$ uman behavior, 17, 59-81

Vygotsky, L. (1978) M ind in society. C ambridge, $M$ ass: $H$ arvard University Press 